\title{
VALIDATED TREATMENTS AND THERAPEUTIC PERSPECTIVES REGARDING NUTRITHERAPY
}

\author{
H.A. BISCHOFF-FERRARI
}

Director, Centre on Aging and Mobility, University of Zurich, Switzerland. Head of Clinical Research, Dept. of Rheumatology and Institute of Physical Medicine, University Hospital Zurich, Switzerland. Visiting Scientist, Jean Mayer USDA Human Nutrition Research Center on Aging, Tufts Boston, USA.

\begin{abstract}
Nutritherapy seeks to prevent or correct disease by the use of nutritional supplements including vitamins, trace elements, or macronutrients. This chapter of the "Les Entretiens du Carla" reviews the potential of nutritherapy for the prevention or improvement of sarcopenia, which is the progressive reduction in muscle mass and muscle strength prevalent in late-life. It is critical that we review nutrients and their potential to maintain muscle mass and strength which ultimately will help minimize falls and fractures among the older population. Evidence from randomized-controlled trials will be reviewed for muscle mass as well as important sarcopeniarelated endpoints including lower extremity strength and function, as well as falls and fallrelated fractures. This chapter will focus on vitamin D as a compelling strategy with evidence for strength gain, fall and fracture prevention from double-blind randomized controlled trials. The other strategy discussed is increased protein intake although longer-term trials and evidence for clinically important endpoints are limited. Today, there is no consistent data on other micronutrients or macronutrients with an established potential to combat sarcopenia.
\end{abstract}

\section{Introduction}

Nutritherapy seeks to prevent or correct disease by the use of nutritional supplements including vitamins, trace elements, or macronutrients. This chapter of the "Les Entretiens du Carla" reviews the potential of nutritherapy for the prevention or improvement of sarcopenia, which is the progressive reduction in muscle mass and muscle strength prevalent in late-life. It is critical that we review nutrients and their potential to maintain muscle mass and strength which ultimately will help minimize falls and fractures among the older population. Evidence from randomized-controlled trials will be reviewed for muscle mass as well as important sarcopenia-related endpoints including lower extremity strength and function, as well as falls and fallrelated fractures. This chapter will focus on vitamin D as a compelling strategy with evidence for clinically important endpoints. The other strategy discussed is increased protein intake although longer-term evidence and evidence for clinically important endpoints are limited. Today, there is no consistent data on other micronutrients or macronutrients with an established potential to combat sarcopenia.

\section{The sarcopenia challenge in fracture prevention at older age}

Critical for the understanding and prevention of fractures at later age is their close relationship with sarcopenia (muscle weakness) (1), and falling (2, 3). Over $90 \%$ of fractures occur after a fall and fall rates increase with age (4) and poor muscle strength or function (Figure 1) (4). Notably, anti-resorptive treatment alone may not reduce fractures among individuals 80 years and older in the presence of non-skeletal risk factors for fractures, such as muscle weakness and falling, despite an improvement in bone metabolism (5). Moreover, low muscle strength is an independent predictor of functional decline (6) and poor bone quality (7) among older adults.

Today, vitamin D is the only known strategy and only nutritherapy that has the comprehensive potential of strength improvement, as well as evidence for fall and fracture prevention among older individuals as documented in randomized controlled trials (RCTs).

Figure 1

Fall-fracture construct

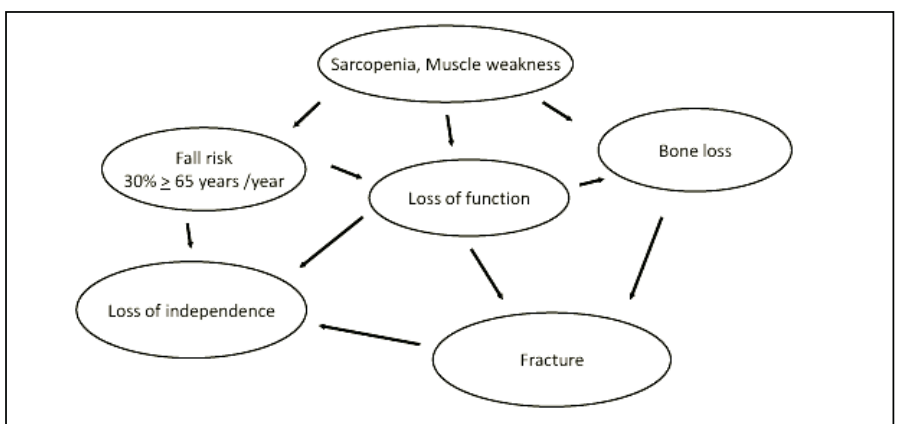

Adapted from Bischoff-Ferrari et al.; Chapter Prevention of Falls in Treatment of Osteoporosis; 2008 Seventh Edition of The Primer on the Metabolic Bone Diseases and Disorders of Mineral Metabolism (American Society of Bone and Mineral Research). The graph illustrates the pivotal contribution of sarcopenia to the fall and fracture construct. Nutritherapy with vitamin D may address each component of the fall-fracture construct as illustrated in Figure 1, including sarcopenia (63), strength (35), balance (38), lower extremity function $(33,34)$, falling $(37,39)$, bone density $(27,71)$, the risk of hip and nonvertebral fractures (51), and the risk of nursing home admission (72).

\section{Vitamin D: prevalence of deficiency and risk factors}

Prevalence of severe vitamin D deficiency (25hydroxyvitamin D levels $<30 \mathrm{nmol} / 1$ or $<12 \mathrm{ng} / \mathrm{ml}$ ) is still high in older individuals, while desirable vitamin $\mathrm{D}$ levels of at least $75 \mathrm{nmol} / \mathrm{l}(30 \mathrm{ng} / \mathrm{ml}$ ) for optimal muscle and bone health is reached by less than $30 \%$ of the US older population and less 


\section{VALIDATED TREATMENTS AND THERAPEUTIC PERSPECTIVES REGARDING NUTRITHERAPY}

than $20 \%$ by the European older population $(8,9)$.

A 1999 landmark publication in the Journal of the American Medical Association (JAMA) by LeBoff and colleagues documented a $50 \%$ prevalence of severe vitamin D deficiency among postmenopausal women admitted with acute hip fracture (serum 25(OH)D levels $<30 \mathrm{nmol} / \mathrm{l})[10]$. The authors suggested in 1999 that heightened awareness is necessary to ensure adequate vitamin D nutrition, especially as vitamin D deficiency is preventable. The high prevalence of severe vitamin D deficiency among hip fracture patients has been confirmed in the early and late nineties by several studies from Europe (11-19). According to Swiss data published in 2008, the prevalence of severe $25(\mathrm{OH}) \mathrm{D}$ deficiency is still significant and basically unchanged compared to earlier data with a more than $50 \%$ prevalence of severe deficiency among hip fracture patients admitted from home and a $75 \%$ prevalence of severe deficiency among those admitted from institutions (20). Notably, less than $10 \%$ of 222 hip fracture patients investigated had any dose of vitamin D supplementation upon admission to acute care (20).

Most vulnerable to low vitamin D levels are older individuals $(21,22)$, individuals living in northern latitudes with prolonged winters $(23,24)$, obese individuals $(25)$, and African Americans of all ages (26-28). Older individuals are at high risk of low vitamin D status because of the decreased production of vitamin $\mathrm{D}$ in the skin with age after sun exposure, which is 4-fold lower compared to younger adults (29). Furthermore, among older adults and within Europe lowest 25hydroxyvitamin D levels are measured in Southern Europe (30), which may be explained by sun avoidance and sun protection at older age. Finally, nutritional sources of vitamin D are rare and are mostly limited to fatty fish, such as salmon, which is not regularly consumed in 2 servings and each day (31). Additionally, food fortification with vitamin D is not practiced in Europe as it is in the US, although the small benefit of about 200 IU vitamin D through consumption of fortified milk or orange juice in the US is small and did not prevent a further decline in 25- hydrocyvitamin D status among US adults as documented in the newest NHANES study (oral presentation of Prof. Bess Dawson-Hughes; IANA conference Boston 2007).

\section{Vitamin D: its role in muscle health}

In humans, four lines of evidence support a role of vitamin D in muscle health and the prevention of sarcopenia. First, proximal muscle weakness is a prominent feature of the clinical syndrome of vitamin D deficiency. Second, VDR is expressed in human muscle tissue, and VDR activation may promote de novo protein synthesis in muscle (32). Third, several observational studies suggest a positive association between 25 hydroxyvitamin D and muscle strength or lower extremity function in older persons $(33,34)$. Finally, in several doubleblind randomized controlled trials, vitamin D supplementation increased muscle strength and balance $(35,36)$, and reduced the risk of falling in community-dwelling individuals (36-38), as well as in institutionalized individuals $(35,39)$. Notably, a study by Glerup and colleagues suggest that vitamin D deficiency may cause muscular impairment even before adverse effects on bone occur (40).

Mice without the VDR develop a skeletal muscle phenotype with smaller and variable muscle fibers and persistence of immature muscle gene expression during adult life (41). These abnormalities persist after correction of systemic calcium metabolism by a rescue diet (42).

\section{Vitamin D: desirable vitamin D status for better function and lower risk of sarcopenia}

A dose-response relationship between vitamin $\mathrm{D}$ status and muscle health was examined in NHANES III including 4100 ambulatory adults age 60 years and older. Muscle function measured as the 8-foot walk test and the repeated sit-to-stand test was poorest in subjects with the lowest 25 -hydroxyvitamin D (below $20 \mathrm{nmol} / \mathrm{l}$ ) levels. Similar results were found in a Dutch cohort of older individuals (33). Notably, while from the smaller Dutch cohort a threshold of $50 \mathrm{nmol} / \mathrm{l}$ has been suggested for optimal function (33), a threshold beyond which function would not further improve was not identified in NHANES III even beyond the upper end of the reference range (> $100 \mathrm{nmol} / \mathrm{l}$ )[34] with a similar benefit by gender, level of physical activity, and calcium intake. With respect to sarcopenia, appendicular skeletal muscle mass was measured in the Dutch cohort among 331 older adults using dual-energy xray absorptiometry. After a 3-yr follow-up, and after adjustment for physical activity level, season of data collection, serum creatinine concentration, chronic disease, smoking, and body mass index, persons with low $(<25 \mathrm{nmol} / \mathrm{l})$ baseline 25 hydroxyvitamin D levels were 2.14 (0.73-6.33, based on muscle mass) times more likely to experience sarcopenia, compared with those with higher $(>50 \mathrm{nmol} / \mathrm{l})$ levels. The associations were similar in men and women.

\section{Vitamin D: weakness / sarcopenia}

Muscle weakness is a prominent feature of the clinical syndrome of vitamin D deficiency. Clinical findings in vitamin D deficiency myopathy include proximal muscle weakness, diffuse muscle pain, and gait impairments such as waddling way of walking (43). The VDR is expressed in human muscle tissue (44), and vitamin D bound to its nuclear receptor in muscle tissue may lead to de novo protein synthesis $(32,45)$. One uncontrolled biopsy trial in postmenopausal women with osteoporosis documented a relative increase in the diameter and number of type II muscle fibers after a 3 month treatment with 1-alpha-calcidiol (32). These findings were confirmed by three recent double-blind RCTs with 800 IU vitamin D3 resulting in a $4-11 \%$ gain in lower extremity strength or function $(35,36)$, and an up to $28 \%$ improvement in body sway $(36,38)$ in older adults age $65+$ between 2 to 12 month of treatment. 


\section{Vitamin D: fall prevention}

Summarizing 5 high-quality double-blind RCTs $(\mathrm{n}=1237)$, a meta-analysis published in 2004 found that vitamin D reduced the risk of falling by $22 \%$ (pooled corrected $\mathrm{OR}=0.78 ; 95 \% \mathrm{CI}$ $[0.64,0.92])$ compared to calcium or placebo (46). This risk reduction was independent of the type of vitamin $\mathrm{D}$, duration of therapy, and gender. For the two trials with 259 subjects using $800 \mathrm{IU}$ of cholecalciferol per day over 2 to 3 months $(35,38)$, the corrected pooled OR was 0.65 (95\% CI $[0.40,1.00])(46)$, while $400 \mathrm{IU}$ was insufficient in reducing falls (47). The importance of dose of vitamin $\mathrm{D}$ in regard to anti-fall efficacy was confirmed by one multi-dose double-blind RCT among 124 nursing home residents receiving 200, 400, 600 or $800 \mathrm{IU}$ vitamin D compared to placebo over a 5 month period (39). Participants in the 800 IU group had a $72 \%$ lower rate of falls than those taking placebo or a lower dose of vitamin D (rate ratio $=0.28 ; 95 \%$ confidence interval $=0.11-0.75)(39)$.

Long-term supplementation over 3 years with 700 IU D3 plus $500 \mathrm{mg}$ calcium among community-dwelling older women reduced the odds of falling by $46 \%$ ( $O R=0.54 ; 95 \%$ confidence interval, 0.30-0.97) (37). Similarly, long-term supplementation among institutionalized individuals with ergocalciferol for 2 years, initially 10,000 IU given once weekly and then 1,000 IU daily, reduced the incident rate ratio for falling by $26 \%(\mathrm{RR}=0.73,95 \% \mathrm{CI}, 0.57-0.95)$ (48). A $49 \%$ fall reduction among older individuals with a history of a fall was demonstrated in a most recent 12-month trial with $1000 \mathrm{IU}$ ergocalciferol compared to placebo $(\mathrm{OR}=0.61 ; 95 \%$ confidence interval [CI], 0.37-0.99) (49).

The most up-to-date meta-analysis with a focus on anti-fall efficacy from 8 high-quality double-blind RCTs of supplemental confirms a benefit of vitamin D supplementation on fall prevention at a dose of at least $700 \mathrm{IU}$ vitamin $\mathrm{D}$ per day (1).

\section{Vitamin D: anti-fracture efficacy}

A 2009 meta-analysis of 12 double-blind RCTs for nonvertebral fractures $(n=42,279)$ and 8 RCTs for hip fractures $(n=$ $40,886)$ found that anti-fracture efficacy of vitamin D is dosedependent and increases significantly with a higher achieved level of 25-hydroxyvitamin D in the treatment group starting at $75 \mathrm{nmol} / \mathrm{l}$ (2). No fracture reduction was observed for a received dose of $400 \mathrm{IU}$ or less per day, while a higher received dose of 482 to $770 \mathrm{IU}$ supplemental vitamin D per day reduced non-vertebral fractures by $20 \%$ (pooled $\mathrm{RR}=0.80 ; 95 \% \mathrm{CI}$, $0.72-0.89 ; \mathrm{n}=33,265$ from 9 trials) and hip fractures by $18 \%$ (pooled RR $=0.82 ; 95 \% \mathrm{CI}, 0.69-0.97 ; \mathrm{n}=31,872$ from 5 trials). Notably, subgroup analyses for the prevention of nonvertebral fractures with the higher received dose suggested a significant benefit in all subgroups of the older population, independent of dwelling, age and additional calcium supplementation (see Table 1).

\section{Table 1}

Non-vertebral fracture reduction with vitamin D based on evidence from double-blind RCTs

\begin{tabular}{lll}
\hline $\begin{array}{l}\text { Subgroups by received dose } \\
\text { of vitamin D }\end{array}$ & \multicolumn{2}{l}{ Fracture reduction } \\
\hline $\begin{array}{l}\text { Pooled analysis from 3 trials with } \\
\text { low-dose vitamin D (340-380 IU / day) }\end{array}$ & $+2 \%$ & $\varnothing$ \\
& & \\
& & \\
Pooled analysis from 9 trials with & $-20 \%$ & Sig. \\
higher dose vitamin D (482-770 IU / day): & & \\
$\quad \begin{array}{l}\text { Pooled subgroup analysis from trials with } \\
\text { higher dose vitamin D (482-770 IE / Tag): }\end{array}$ & & \\
$\quad-$ Vitamin D2 & $-10 \%$ & $\varnothing$ \\
$\quad$ - Vitamin D3 & $-23 \%$ & Sig. \\
$\quad$ - age 65-74 & $-33 \%$ & Sig. \\
$\quad$ - age 75+ & $-17 \%$ & Sig. \\
$\quad$ - institutionalized 65+ & $-15 \%$ & Sig. \\
$\quad$ - community-dwelling 65+ & $-29 \%$ & Sig. \\
$\quad$ - Vitamin D plus Calcium & $-21 \%$ & Sig. \\
- Vitamin D main effects & $-21 \%$ & Sig. \\
\hline
\end{tabular}

Legend: Adapted from Bischoff-Ferrari et al. Prevention of non-vertebral fractures with oral vitamin D and dose dependency: a meta-analysis of randomized controlled trials. Arch Intern Med. 2009 Mar 23;169(6):551-61., Copyright@ (2009), American Medical Association (2).

\section{Vitamin D: dosing and safety}

Vitamin $D$ intakes that may be required to achieve the optimal levels of $25(\mathrm{OH}) \mathrm{D}$ in most individuals are not established. Studies suggest that 700 to 1000 IU of vitamin D per day may bring $50 \%$ of younger and older adults up to 75 $100 \mathrm{nmol} / \mathrm{l}$ (54-56). Thus, to bring most adults to the desirable range of 75-100 nmol/l, vitamin D doses higher than 700-1000 IU would be needed. The current intake recommendation for older persons (600 IU per day) may bring most subjects to 50$60 \mathrm{nmol} / \mathrm{l}$, but not to $75-100 \mathrm{nmol} / \mathrm{l}$ (27). A recent risk assessment on vitamin D based on relevant, well-designed human clinical trials of vitamin D documented the absence of toxicity in trials conducted in healthy adults that used vitamin D dose 10,000 IU vitamin D3 (57). The authors thus suggested an upward adjustment of the safe upper limit from currently 2000 IU to 10,000 IU per day. Higher dose trials in older populations using 2000 IU vitamin D per day are being conducted for strength and fall endpoints. In clinical practice, older adults or obese individuals often start treatment from severe deficiency which requires higher doses of vitamin $D$ to achieve the shift into the adequate range of 25-hydroxyvitamin D status $(58,59)$. In these situations a starting oral bolus of 30,000 to 100 '000 IU once (60) followed by a daily or intermittend regimen with vitamin D is useful. Monitoring of 25-hydroxyvitamin D levels may be ideal to ensure sufficient vitamin D supplementation with a target range of 25 hydroxyvitamin D between 75 to $100 \mathrm{nmol} / \mathrm{l}$ (9). With a halflife of about 1.5 month, a control 25-hydroxyvitamin D serum level after 6 weeks of treatment is valuable. 


\section{Vitamin D: Combination with Calcium}

Emerging data suggests that vitamin D may reduce falls and fractures independent of additional calcium supplementation provided the vitamin D intake is adequate (at least $800 \mathrm{IU}$ per day) and dietary calcium intake is between 700 to $800 \mathrm{mg}$ per day $(2,50,51,53)$. This is of clinical importance as calcium supplementation is not well tolerated in older adults resulting in low adherence to treatment (61).

Furthermore, with a lower minimal target for total calcium intake of 700-800 $\mathrm{mg}$ per day (the recommended minimal intake in the UK is $700 \mathrm{mg}$ /day as oppose to $1200 \mathrm{mg}$ in the US), dietary requirements may be met by nutritional intakes alone. Milk products could serve as a source of not only calcium but also high-quality protein, which may be a compelling strategy in the combat of sarcopenia if combined with a vitamin D supplement (see protein section).

\section{Vitamin D: summary and future research}

In summary, although RCT data regarding the vitamin D effect on sarcopenia are missing, high-quality RCT data for strength, balance, function, falls and fractures endpoints are appealing and show a significant benefit of vitamin $\mathrm{D}$ at a dose of at least $700 \mathrm{IU}$ vitamin D per day. Additional data discussed in this chapter linking vitamin D to sarcopenia prevention are several: the documented presence of the VDR in human muscle tissue and its decline with age (62), prospective cohort data that suggest a 2-fold increased risk of sarcopenia measured by DEXA in older individuals with severe vitamin D deficiency (63), uncontrolled trial data that suggest a relative increase in type II muscle fibres with vitamin D treatment (32), and a clear dose- reponse association between higher 25-hydroxyvitamin D levels and lower extremity function from 2 epidemiologic studies $(33,34)$.

The dose-response relationships between higher doses of vitamin $\mathrm{D}$ or higher achieved 25-hydroxyvitamin D levels on the one hand and better function, greater fall and fracture reduction on the other, suggest that higher doses of vitamin D beyond 700-800 IU per day should be explored in future research to optimize prevention of sarcopenia and its adverse events.

\section{Protein: Its potential and complexities}

Daily consumption of protein declines with age, while there is general agreement that a sufficient protein intake may enhance muscle protein anabolism. A decrease in protein intake is therefore viewed as a likely contributor to age-related sarcopenia. Importantly, several studies suggest that the recommended daily allowance for protein may not be adequate for older people to maintain skeletal muscle mass $(64,65)$. Conceptually, the estimation of the RDA has several limitations, one being that it was calculated based on nitrogen balance studies, which is not a clinically relevant endpoint. Another being that the data were collected among young men, which may not extrapolate to older people who likely need a higher protein intake to maintain their nitrogen balance (64). However, even with the current target RDA of $0.8 \mathrm{~g} / \mathrm{kg}^{*} \mathrm{~d}$ for all adults, between $15-38 \%$ of adult men and $27-41 \%$ of adult women have dietary protein intakes below the RDA (64).

Beyond the lack of long-term data, the complexity of a higher protein recommendation among older persons are several: one concern is that renal function declines with age and high protein intake, particularly high intake of nondairy animal protein, may accelerate renal function decline in those with mild renal insufficiency (66). Some data also suggest that aging impairs digestability and bioavailability of some protein sources (67). For milk protein, protein gain was greater with whey protein (rapidly digested protein), and lower with caseins (slowly digested protein) in older men as opposed to younger men where the pattern was inverse (67).

Furthermore, it has been shown that other non-protein energy sources, such as carbohydrates affect protein metabolism, which may be most pronounced in older persons (68). Finally, protein supplementation in older persons may result in a compensatory decrease of voluntary food intake (69).

These complexities and lack of longer-term data for important clinical endpoints challenge future research in sarcopenia prevention with higher protein intake (70).

\section{References}

1. Bischoff-Ferrari, H.A., et al., Fall prevention with supplemental and alphahydroxylated vitamin D: a meta-analysis of randomized controlled trials British Medical Journal; in press, 2009.

2. Bischoff-Ferrari, H.A., et al., Prevention of nonvertebral fractures with oral vitamin $\mathrm{D}$ and dose dependency: a meta-analysis of randomized controlled trials. Arch Intern Med, 2009. 169(6): p. 551-61.

3. Schwartz AV, Nevitt MC, Brown BW, Jr., Kelsey JL: Increased falling as a risk factor for fracture among older women: the study of osteoporotic fractures. Am J Epidemiol. 2005; 161(2): 180-5.

4. Tinetti ME: Risk factors for falls among elderly persons living in the community. $\mathrm{N}$ Engl J Med 1988; 319: 1701-1707.

5. McClung MR, Geusens P, Miller PD, et al.: Effect of risedronate on the risk of hip fracture in elderly women. Hip Intervention Program Study Group. N Engl J Med. 2001; 344(5): 333-40.

6. Tinetti ME, Williams CS: The effect of falls and fall injuries on functioning in community-dwelling older persons. J Gerontol A Biol Sci Med Sci 1998; 53(2): M112-9.

7. Szulc P, Beck TJ, Marchand F, Delmas PD: Low skeletal muscle mass is associated with poor structural parameters of bone and impaired balance in elderly men--the MINOS study. J Bone Miner Res 2005; 20(5): 721-9.

8. Dawson-Hughes B: Consensus statement on optimal 25-hydroxyvitamin D levels. 5th International Symposium on Nutritional Aspects of Osteoporosis in Lausanne 2003.

9. Bischoff-Ferrari HA, Giovannucci E, Willett WC, Dietrich T, Dawson-Hughes B: Estimation of optimal serum concentrations of 25-hydroxyvitamin D for multiple health outcomes. Am J Clin Nutr 2006; 84(1): 18-28.

10. LeBoff MS, Kohlmeier L, Hurwitz S, Franklin J, Wright J, Glowacki J: Occult vitamin D deficiency in postmenopausal US women with acute hip fracture. Jama 1999; 281(16): 1505-11.

11. Thiebaud D, Burckhardt P, Costanza M, et al.: Importance of albumin, 25(OH)vitamin D and IGFBP-3 as risk factors in elderly women and men with hip fracture. Osteoporos Int 1997; 7(5): 457-62.

12. Punnonen R, Salmi J, Tuimala R, Jarvinen M, Pystynen P: Vitamin D deficiency in women with femoral neck fracture. Maturitas. 1986; 8(4): 291-5.

13. Benhamou CL, Tourliere D, Gauvain JB, Picaper G, Audran M, Jallet P: Calciotropic hormones in elderly people with and without hip fracture. Osteoporos Int. 1995; 5(2): 103-7.

14. Lips P, Netelenbos JC: [Vitamin D deficiency and hip fracture]. Tijdschr Gerontol Geriatr. 1985; 16(6): 239-45.

15. Scharla SH, Wolf S, Dull R, Lempert UG: Prevalence of low bone mass and endocrine disorders in hip fracture patients in Southern Germany. Exp Clin Endocrinol Diabetes. 1999; 107(8): 547-54.

16. Quesada-Gomez JM, Alonso J, Bouillon R: Vitamin D insufficiency as a determinant of hip fractures. Osteoporos Int. 1996; 6(Suppl 3): 42-7. 
17. Boonen S, Broos P, Verbeke G, et al.: Calciotropic hormones and markers of bone remodeling in age-related (type II) femoral neck osteoporosis: alterations consistent with secondary hyperparathyroidism-induced bone resorption. J Gerontol A Biol Sci Med Sci. 1997; 52(5): M286-93.

18. Falch JA, Mowe M, Bohmer T, Haug E: Serum levels of intact parathyroid hormone in elderly patients with hip fracture living at home. Acta Endocrinol (Copenh). 1992; 126(1): 10-2.

19. Compston JE, Silver AC, Croucher PI, Brown RC, Woodhead JS: Elevated serum intact parathyroid hormone levels in elderly patients with hip fracture. Clin Endocrinol (Oxf). 1989; 31(6): 667-72.

20. Bischoff-Ferrari HA, Can U, Staehelin HB, et al.: Severe vitamin D deficiency in Swiss hip fracture patients. Bone 2008; 42(3): 597-602.

21. McKenna MJ: Differences in vitamin D status between countries in young adults and the elderly. Am J Med 1992; 93(1): 69-77.

22. Theiler R, Stahelin HB, Tyndall A, Binder K, Somorjai G, Bischoff HA: Calcidiol, calcitriol and parathyroid hormone serum concentrations in institutionalized and ambulatory elderly in Switzerland. Int J Vitam Nutr Res 1999; 69(2): 96-105.

23. Webb AR, Kline L, Holick MF: Influence of season and latitude on the cutaneous synthesis of vitamin D3: exposure to winter sunlight in Boston and Edmonton will not promote vitamin D3 synthesis in human skin. J Clin Endocrinol Metab 1988; 67(2): 373-8.

24. Dawson-Hughes B, Harris SS, Dallal GE: Plasma calcidiol, season, and serum parathyroid hormone concentrations in healthy elderly men and women. Am J Clin Nutr 1997; 65(1): 67-71.

25. Parikh SJ, Edelman M, Uwaifo GI, et al.: The relationship between obesity and serum 1,25-dihydroxy vitamin D concentrations in healthy adults. J Clin Endocrinol Metab 2004; 89(3): 1196-9.

26. Looker AC, Dawson-Hughes B, Calvo MS, Gunter EW, Sahyoun NR: Serum 25hydroxyvitamin D status of adolescents and adults in two seasonal subpopulations from NHANES III. Bone 2002; 30(5): 771-7.

27. Bischoff-Ferrari HA, Dietrich T, Orav EJ, Dawson-Hughes B: Positive association between 25-hydroxy vitamin d levels and bone mineral density: a population-based study of younger and older adults. Am J Med 2004; 116(9): 634-9.

28. Nesby-O'Dell S, Scanlon KS, Cogswell ME, et al.: Hypovitaminosis D prevalence and determinants among African American and white women of reproductive age: third National Health and Nutrition Examination Survey, 1988-1994. Am J Clin Nutr 2002; 76(1): 187-92.

29. Holick MF: Environmental factors that influence the cutaneous production of vitamin D. Am J Clin Nutr 1995; 61(suppl): 638S-45S.

30. van der Wielen RP, Lowik MR, van den Berg H, et al.: Serum vitamin D concentrations among elderly people in Europe. Lancet. 1995; 346(8969): 207-10.

31. Chen TC, Chimeh F, Lu Z, et al.: Factors that influence the cutaneous synthesis and dietary sources of vitamin D. Arch Biochem Biophys 2007; 460(2): 213-7.

32. Sorensen $\mathrm{OH}$, Lund B, Saltin B, et al.: Myopathy in bone loss of ageing: improvement by treatment with 1 alpha-hydroxycholecalciferol and calcium. Clin Sci (Colch) 1979; 56(2): 157-61.

33. Wicherts IS, van Schoor NM, Boeke AJ, et al.: Vitamin D status predicts physical performance and its decline in older persons. J Clin Endocrinol Metab 2007; 6 : 6 .

34. Bischoff-Ferrari HA, Dietrich T, Orav EJ, et al.: Higher 25-hydroxyvitamin D concentrations are associated with better lower-extremity function in both active and inactive persons aged $>=60 \mathrm{y}$. Am J Clin Nutr 2004; 80(3): 752-8.

35. Bischoff HA, Stahelin HB, Dick W, et al.: Effects of vitamin D and calcium supplementation on falls: a randomized controlled trial. J Bone Miner Res 2003; 18(2): 343-51.

36. Pfeifer M, Begerow B, Minne HW, Suppan K, Fahrleitner-Pammer A, Dobnig H: Effects of a long-term vitamin D and calcium supplementation on falls and parameters of muscle function in community-dwelling older individuals. Osteoporos Int 2008; 16: 16.

37. Bischoff-Ferrari HA, Orav EJ, Dawson-Hughes B: Effect of cholecalciferol plus calcium on falling in ambulatory older men and women: a 3-year randomized controlled trial. Arch Intern Med. 2006; 166(4): 424-30.

38. Pfeifer M, Begerow B, Minne HW, Abrams C, Nachtigall D, Hansen C: Effects of a short-term vitamin D and calcium supplementation on body sway and secondary hyperparathyroidism in elderly women. J Bone Miner Res 2000; 15(6): 1113-8.

39. Broe KE, Chen TC, Weinberg J, Bischoff-Ferrari HA, Holick MF, Kiel DP: A higher dose of vitamin d reduces the risk of falls in nursing home residents: a randomized, multiple-dose study. J Am Geriatr Soc 2007; 55(2): 234-9.

40. Glerup H, Mikkelsen K, Poulsen L, et al.: Hypovitaminosis D myopathy without biochemical signs of osteomalacic bone involvement. Calcif Tissue Int 2000; 66(6): 419-24.

41. Bouillon R, Bischoff-Ferrari H, Willett W: Vitamin D and Health: Perspectives from Mice and Man. J Bone Miner Res 2008; 28: 28.

42. Endo I, Inoue D, Mitsui T, et al.: Deletion of vitamin D receptor gene in mice results in abnormal skeletal muscle development with deregulated expression of myoregulatory transcription factors. Endocrinology 2003; 144(12): 5138-44. Epub 2003 Aug 13.

43. Schott GD, Wills MR: Muscle weakness in osteomalacia. Lancet. 1976; 1(7960): 626-9.

44. Bischoff-Ferrari HA, Borchers M, Gudat F, Durmuller U, Stahelin HB, Dick W: Vitamin D receptor expression in human muscle tissue decreases with age. J Bone
Miner Res 2004; 19(2): 265-9

45. Boland R: Role of vitamin D in skeletal muscle function. Endocrine Reviews 1986; 7: 434-447.

46. Bischoff-Ferrari HA, Dawson-Hughes B, Willett CW, et al.: Effect of vitamin D on falls: a meta-analysis. JAMA 2004; 291(16): 1999-2006.

47. Graafmans WC, Ooms ME, Hofstee HM, Bezemer PD, Bouter LM, Lips P: Falls in the elderly: a prospective study of risk factors and risk profiles. Am J Epidemiol 1996; 143(11): 1129-36.

48. Flicker L, MacInnis RJ, Stein MS, et al.: Should older people in residential care receive vitamin D to prevent falls? Results of a randomized trial. J Am Geriatr Soc 2005; 53(11): 1881-8.

49. Prince RL, Austin N, Devine A, Dick IM, Bruce D, Zhu K: Effects of ergocalciferol added to calcium on the risk of falls in elderly high-risk women. Arch Intern Med 2008; 168(1): 103-8.

50. Bischoff-Ferrari HA, Dawson-Hughes B, Staehelin HB, et al.: Anti-fall efficacy of supplemental and alpha-hydroxylated vitamin D: a meta-analysis of randomized controlled trials. Journal of Bone and Mineral Research 2008; 23(September 2008): abstract S350.

51. Bischoff-Ferrari HA, Willett WC, Wong JB, Giovannucci E, Dietrich T, DawsonHughes B: Fracture prevention with vitamin D supplementation: a meta-analysis of randomized controlled trials. Jama 2005; 293(18): 2257-64.

52. Bischoff-Ferrari HA, Dawson-Hughes B, Baron JA, et al.: Calcium intake and hip fracture risk in men and women: a meta-analysis of prospective cohort studies and randomized controlled trials. Am J Clin Nutr 2007; 86(6): 1780-90.

53. Bischoff-Ferrari HA, Willett WC, Wong JB, et al.: Prevention of non-vertebral fractures with oral vitamin D is dose dependent: a Meta-analysis of RCTs. Journal of Bone and Mineral Research 2008; 23(September 2008): S68 (abstract 1242).

54. Tangpricha V, Pearce EN, Chen TC, Holick MF: Vitamin D insufficiency among free-living healthy young adults. Am J Med 2002; 112: 659-62.

55. Barger-Lux MJ, Heaney RP, Dowell S, Chen TC, Holick MF: Vitamin D and its major metabolites: serum levels after graded oral dosing in healthy men. Osteoporos Int 1998; 8(3): 222-30.

56. Dawson-Hughes B: Impact of vitamin D and calcium on bone and mineral metabolism in older adults. Biologic Effects of Light 2001. Holick MF (ed). Kluwer Academic Publishers, Boston, MA 2002: 175-83.

57. Hathcock JN, Shao A, Vieth R, Heaney R: Risk assessment for vitamin D. Am J Clin Nutr 2007; 85(1): 6-18.

58. Heaney RP: Functional indices of vitamin D status and ramifications of vitamin D deficiency. Am J Clin Nutr 2004; 80(6 Suppl): 1706S-9S.

59. Heaney RP: The Vitamin D requirement in health and disease. J Steroid Biochem Mol Biol 2005; 15: 15.

60. Ilahi M, Armas LA, Heaney RP: Pharmacokinetics of a single, large dose of cholecalciferol. Am J Clin Nutr. 2008; 87(3): 688-91.

61. Grant AM, Avenell A, Campbell MK, et al.: Oral vitamin D3 and calcium for secondary prevention of low-trauma fractures in elderly people (Randomised Evaluation of Calcium Or vitamin D, RECORD): a randomised placebo-controlled trial. Lancet 2005; 365(9471): 1621-8.

62. Bischoff HA, Borchers M, Gudat F, Dürmüller U, Stähelin HB, Dick W: Vitamin D receptor expression in human muscle tissue is reduced with age. $\mathrm{J}$ Bone Miner Res 2001; 23rd Annual Meeting of the ASBMR(Abstract).

63. Visser M, Deeg DJ, Lips P: Low vitamin D and high parathyroid hormone levels as determinants of loss of muscle strength and muscle mass (sarcopenia): the Longitudinal Aging Study Amsterdam. J Clin Endocrinol Metab 2003; 88(12): 5766 72.

64. Campbell WW, Trappe TA, Wolfe RR, Evans WJ: The recommended dietary allowance for protein may not be adequate for older people to maintain skeletal muscle. J Gerontol A Biol Sci Med Sci. 2001; 56(6): M373-80.

65. Wolfe RR, Miller SL: The recommended dietary allowance of protein: a misunderstood concept. Jama. 2008; 299(24): 2891-3.

66. Knight EL, Stampfer MJ, Hankinson SE, Spiegelman D, Curhan GC: The impact of protein intake on renal function decline in women with normal renal function or mild renal insufficiency. Ann Intern Med. 2003; 138(6): 460-7.

67. Dangin M, Guillet C, Garcia-Rodenas C, et al.: The rate of protein digestion affects protein gain differently during aging in humans. J Physiol. 2003; 549(Pt 2): 635-44. Epub 2003 Mar 28.

68. Volpi E, Mittendorfer B, Rasmussen BB, Wolfe RR: The response of muscle protein anabolism to combined hyperaminoacidemia and glucose-induced hyperinsulinemia is impaired in the elderly. J Clin Endocrinol Metab. 2000; 85(12): 4481-90.

69. Paddon-Jones D, Westman E, Mattes RD, Wolfe RR, Astrup A, WesterterpPlantenga M: Protein, weight management, and satiety. Am J Clin Nutr. 2008; 87(5): 1558S-1561S.

70. Paddon-Jones D, Short KR, Campbell WW, Volpi E, Wolfe RR: Role of dietary protein in the sarcopenia of aging. Am J Clin Nutr. 2008; 87(5): 1562S-1566S.

71. Dawson-Hughes B, Harris SS, Krall EA, Dallal GE: Effect of calcium and vitamin D supplementation on bone density in men and women 65 years of age or older. N Engl J Med 1997; 337(10): 670-6.

72. Visser M, Deeg DJ, Puts MT, Seidell JC, Lips P: Low serum concentrations of 25hydroxyvitamin D in older persons and the risk of nursing home admission. Am J Clin Nutr. 2006; 84(3): 616-22; quiz 671-2. 